\title{
Anelastic Behaviour of Commercial Die-Cast Magnesium Alloys: Effect of Temperature and Alloy Composition
}

\author{
Hua Qian Ang
}

check for

updates

Citation: Ang, H.Q. Anelastic Behaviour of Commercial Die-Cast Magnesium Alloys: Effect of Temperature and Alloy Composition. Materials 2021, 14, 7220. https:// doi.org/10.3390/ma14237220

Academic Editor: Bolv Xiao

Received: 13 October 2021

Accepted: 23 November 2021

Published: 26 November 2021

Publisher's Note: MDPI stays neutral with regard to jurisdictional claims in published maps and institutional affiliations.

Copyright: (C) 2021 by the author. Licensee MDPI, Basel, Switzerland. This article is an open access article distributed under the terms and conditions of the Creative Commons Attribution (CC BY) license (https:/ / creativecommons.org/licenses/by/ $4.0 /)$.
School of Engineering, RMIT University, Melbourne, VIC 3000, Australia; huaqian.ang@rmit.edu.au

\begin{abstract}
The anelastic deformation, resulting from partial reversal of $\{10 \overline{1} 2\}$ twinning, is studied at room temperature to $150{ }^{\circ} \mathrm{C}$ on several commercial die-cast magnesium alloys for the first time. The magnitude of anelastic strain decreases with increasing temperature. For inter-alloy comparison, AZ91 shows the largest maximum anelastic strain, while AM40 and AM60 show similar maximum anelastic strain. The phenomenon is discussed in terms of solid solution softening and hardening of slip planes and how they influence twinning. T5-aged AE44 consistently shows smaller magnitude of anelasticity compared to as-cast AE44, suggesting that the precipitates formed during ageing may decrease the twin-boundary mobility and further suppress untwinning. Presence of anelasticity poses a challenge to yield strength measurement using the conventional $0.2 \%$ offset method, and a more accurate and consistent method of using a higher offset strain or a lower modulus is proposed in this study.
\end{abstract}

Keywords: magnesium alloys; anelasticity; mechanical properties; elastic modulus; yield strength; die casting

\section{Introduction}

The hexagonal closed-packed (HCP) crystal structure of magnesium (Mg) provides only two independent basal slip systems [1], while the non-basal slips (i.e., prismatic and pyramidal slip) only activate at higher stress levels at room temperature (RT) [2-4]. To meet the requirements of von Mises' criterion, which needs five independent systems for homogeneous plastic deformation $[5,6],\{10 \overline{1} 2\}<10 \overline{1} 1>$ extension twinning is activated at low stresses and strains $[7,8]$. These $\{10 \overline{1} 2\}$ twins are unstable in the loaded condition [9], and they can partially revert upon unloading [10]. The partial reversal of $\{10 \overline{1} 2\}$ twinning is the main cause for anelasticity in $\mathrm{Mg}$ and $\mathrm{Mg}$ alloys [11-13], manifesting as large hysteresis loops in the cyclic stress-strain curve as observed in pure $\mathrm{Mg}$ [11], $\mathrm{Mg}-\mathrm{Zn}$ alloys [14,15], Mg-Gd alloys [16], Mg-Al alloys [12,17], AZ31 (Mg-3Al-1Zn, all compositions in weight percent hereafter unless specified) [18], AZ91 (Mg-9Al-0.6Zn) [19], AM60 (Mg-6Al-0.3Mn) [20] and AE44 (Mg-4Al-4RE) [21].

Anelasticity allows $\mathrm{Mg}$ and $\mathrm{Mg}$ alloys to deform reversibly beyond the linear elastic region, and this poses a challenge to conventional yield strength measurement [22]. Moreover, with a linear stress-strain relationship, a single elastic modulus value can easily be determined, but with the presence of anelasticity (non-linear stress-strain relationship), the secant elastic modulus (effective modulus) has been shown to vary with strain [20]. This creates a problem for the engineering designs that are based on a constant value of the elastic modulus. Hence, the study of anelastic deformation is important to understand the stiffness and yielding behaviour of $\mathrm{Mg}$ alloys.

High-pressure die-cast alloys constitute for over $90 \%$ of $\mathrm{Mg}$ alloy usage $[23,24]$, and they exhibit significant anelastic deformation due to their small grain size. Firstly, smallgrained alloy contains fine and unstable twins, and they are more likely to revert upon unloading. Secondly, the number of grains favourably oriented for twinning is also larger for small grain size. These two factors were reported to account for the large anelastic strain in small-grained die-cast alloys [14,19]. 
Anelastic behaviour is also influenced by the solute content. Anelasticity was observed to be the largest in pure $\mathrm{Mg}$, and anelasticity decreased with increasing $\mathrm{Zn} \mathrm{[14]} \mathrm{and} \mathrm{Gd} \mathrm{[16]}$ solute concentrations. The effect of solute is, however, different for $\mathrm{Mg}-\mathrm{Al}$ alloys. In $\mathrm{Mg}-\mathrm{Al}$ alloys, the anelasticity was observed to be almost similar at low Al solute concentrations up to 2 at.\%, increasing again at high Al solute concentrations at 9 at.\% [15,25]. The difference in behaviour between $\mathrm{Mg}-\mathrm{Zn}, \mathrm{Mg}-\mathrm{Gd}$, and $\mathrm{Mg}-\mathrm{Al}$ alloys was attributed to the presence of short-range order (SRO) by the different solutes [15,16]. \{10 $\overline{1} 2\}$ twinning is shuffling dominated [26], and the presence of SRO will make twinning and untwinning more difficult [27]. Both Zn and Gd in solution have a tendency to develop SRO [28] and thus the monotonic decrease of anelasticity with $\mathrm{Zn}$ and $\mathrm{Gd}$ solute concentrations [15,16]. In contrast, Al forms near-random solid solutions [29] and does not have any hardening effect on twinning [15,30]. The increased anelastic strain observed in Mg-9Al [15] and AZ91 [31] was ascribed to solid solution hardening of slip systems at high Al concentrations, making twinning more necessary as a deformation mechanism.

This study focuses on commercially available die-cast Mg alloys, namely AE44, AM40, AM60, and AZ91. These alloys were selected primarily due to their wide application in automotive parts, for example, AE44 in front engine cradle and powertrain components, AM40 and AM60 in energy-absorbing components, such as seat structures and instrument panels, and AZ91 in steering column brackets [32,33].

The effect of strain rate on anelasticity of these die-cast alloys has recently been investigated by the present author [30]. Anelasticity was observed to increase with increasing applied strain rates from $10^{-6}$ to $10^{-1} \mathrm{~s}^{-1}$. This was attributed to the delay onset of prismatic slip at higher strain rate, increasing the alloys' tendency to twin. The anelasticity of AE alloy was also observed to be more strain-rate sensitive than the AM and AZ alloys.

This paper not only serves as an extension to the strain-rate study $[30,34]$, but to the author's knowledge, this is the first study to report on the effect of elevated temperature on the anelastic deformation for Mg alloys. Although the scope of this work is limited to the temperature range from RT to $150{ }^{\circ} \mathrm{C}$ due to limitations of equipment, this study on anelasticity offers an overview of how twinning and untwinning develop during deformation at different temperatures, and how they can be affected by alloy composition. The implications of the temperature dependence of anelasticity and secant elastic modulus on yield strength measurement are also discussed, which may provide a new perspective in future elevated temperature applications of die-cast $\mathrm{Mg}$ alloys.

\section{Materials and Methods}

Mg alloys, AE44, AM40, AM60, and AZ91, used in this study were high-pressure die-cast in a cold chamber machine at CSIRO, Melbourne, Australia. Details of the casting parameters were previously reported [35]. Some as-cast AE44 specimens were subject to an ageing treatment at $200{ }^{\circ} \mathrm{C}$ for $32 \mathrm{~h}$ (labelled T5-aged) in order to improve the strength-ductility combinations due to the precipitation of nanoscale Al-Mn particles upon ageing [36]. Table 1 lists the chemical compositions of the studied alloys analysed using inductively coupled plasma atomic emission spectroscopy (ICP-AES).

Table 1. Chemical compositions of the studied Mg alloys in wt.\%.

\begin{tabular}{cccccc}
\hline Alloy & Al & Mn & RE (Ce + La) & Zn & Mg \\
\hline AE44 & 3.67 & 0.31 & 3.83 & $<0.01$ & Bal. \\
AM40 & 4.44 & 0.21 & $<0.01$ & 0.05 & Bal. \\
AM60 & 6.26 & 0.29 & $<0.01$ & 0.1 & Bal. \\
AZ91 & 8.88 & 0.19 & $<0.01$ & 0.74 & Bal. \\
\hline
\end{tabular}

All specimens used in this study are dog-bone shaped with a cylindrical cross-section diameter of $5.6 \mathrm{~mm}$ and a $36 \mathrm{~mm}$ parallel section in the gauge length, as shown in Figure 1. Monotonic and cyclic tension loading-unloading tests were carried out in a temperaturecontrolled environmental chamber mounted on an Instron universal testing machine. All 
tests were carried out at a crosshead speed of $2 \mathrm{~mm} / \mathrm{min}\left(\dot{\varepsilon} \approx 10^{-3} \mathrm{~s}^{-1}\right)$ at RT of about $22{ }^{\circ} \mathrm{C}(295 \mathrm{~K})$ and at elevated temperatures of $50{ }^{\circ} \mathrm{C}(323 \mathrm{~K}), 100{ }^{\circ} \mathrm{C}(373 \mathrm{~K})$, and $150{ }^{\circ} \mathrm{C}$ $(423 \mathrm{~K})$. Temperature was allowed to equilibrate for $5-10 \mathrm{~min}$ before testing. To accurately measure the temperature, a K-type thermocouple was bent and inserted between the grips of the machine, so that it was contacting the specimen. Temperature variations of $1-2{ }^{\circ} \mathrm{C}$ were observed during testing.

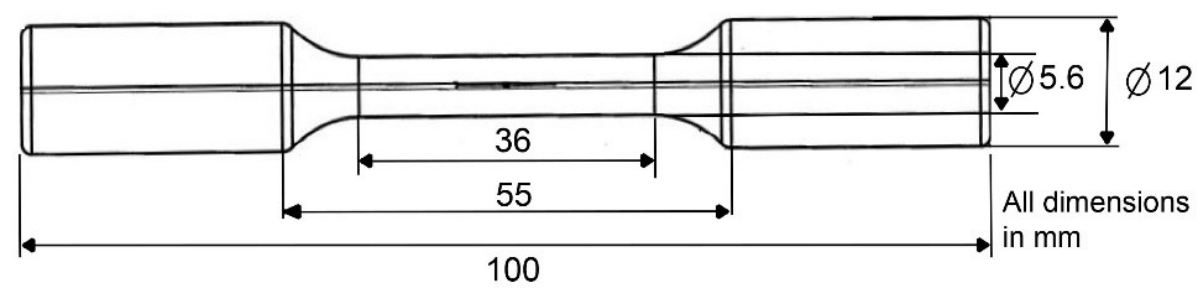

Figure 1. Schematic diagram of the tensile specimen used in this study.

The cyclic tension loading-unloading tests were strain-controlled, loaded to a predetermined strain, unloaded to zero stress, and then reloaded again following the International Standards Organization (ISO) standard [37]. All alloys were cyclic tested to 3\% strain, except AZ91, which was tested to a larger strain of $5 \%$ to determine the saturation of anelastic strain. An extensometer was attached to the specimen gauge area to record the strain values during testing. Each test was repeated two to three times, and good reproducibility of data was observed. Compression testing is not included in this study, as high-pressure die-cast alloys are known to be isotropic in behaviour [38,39].

Microstructures were characterised by a scanning electron microscopy (SEM) equipped with an energy dispersive X-ray (EDX) spectroscopy and an electron backscatter diffraction (EBSD). EDX line scan was conducted to measure the $\mathrm{Al}$ solute concentration level in the $\alpha$-Mg matrix. EBSD data were collected at $20 \mathrm{kV}$ with a $0.5 \mu \mathrm{m}$ step size to reveal the deformation twins. For each sample, three locations were analysed. Samples for microstructural analysis were polished with 600 and $2400 \mathrm{SiC}$ papers followed by 3 and $1 \mu \mathrm{m}$ alcohol-based diamond suspensions and were finished by a $0.06 \mu \mathrm{m}$ colloidal silica suspension.

\section{Results}

A typical cyclic loading-unloading tensile curve is shown in Figure 2, whereby several parameters used in this study are defined. The non-linearity in the unloading curve forms a closed loop upon reloading. If the specimen is unloaded after some applied plastic strain, a larger unloading strain is required to achieve the same amount of plastic strain as under linear elastic behaviour. The monotonic tensile curve also matches with the cyclic curve, indicating that cyclic loading does not have any significant effect on the work-hardening behaviour. The $0.2 \%$ offset line illustrates the yield strength measurement method for $\mathrm{Mg}$ and $\mathrm{Mg}$ alloys based on the American Society for Testing and Materials (ASTM) [40] and ISO [37] standards.

Similar cycles for as-cast AE44 and AZ91 at RT and $150{ }^{\circ} \mathrm{C}$ are shown in Figure 3. As expected, the flow stress decreases with increasing temperature as the alloy becomes more ductile at higher temperature (tensile properties are presented in Table 2). The hysteresis loops also become smaller as temperature increases. Similar behaviour was observed in T5-aged AE44, AM40 and AM60 (not shown). Some AZ91 specimens tested at RT fractured before reaching $5 \%$ strain due to the inherent low RT tensile ductility of the alloy.

The anelastic strain ( $\varepsilon_{\mathrm{ae}}$, defined in Figure 2) measured from the width of the hysteresis loop and the secant elastic modulus ( $\mathrm{E}_{\mathrm{sec}}$, in Figure 2$)$ are plotted as a function of the applied plastic strain for the studied alloys and temperatures in Figures 4 and 5, respectively. In Figure 4, the anelastic strain develops gradually after a small applied plastic strain then reaches a maximum and saturates at between $0.1 \%$ (T5-aged AE44, $150{ }^{\circ} \mathrm{C}$ ) and $0.4 \%$ (AZ91, $\mathrm{RT}$ ), depending on the alloy and temperature. The maximum anelasticity also denotes the 
onset of anelastic saturation, and it is marked by the symbol ' $\mathrm{X}$ '. In AE and AM alloys, the anelasticity saturates after a plastic strain of about $0.8-1 \%$, whilst the AZ91 alloy saturates at a larger plastic strain of about $1.4 \%$ (at $150{ }^{\circ} \mathrm{C}$ ) $-1.8 \%$ (at RT), and hence AZ91 was cyclic tested to a larger strain to see this plateau effect. A slight decrease in anelasticity is also observed in AZ91 beyond 2.4\% plastic strain; strains applied at other alloys are not sufficient to show this effect. In Mg-Al-RE alloy, T5-aged AE44 exhibits a smaller maximum anelasticity as compared to as-cast $\mathrm{AE} 44$, whereas in the $\mathrm{Mg}-\mathrm{Al}$ alloys, AM40 and AM60 exhibit similar maximum anelasticity, whilst AZ91 has the largest maximum anelasticity at a given temperature. Overall, the magnitude of anelasticity decreases with increasing temperature for all the alloys.

In Figure 5, all the alloys start off with an elastic modulus (E, in Figure 2) of $45 \mathrm{GPa}$ regardless of the temperatures, except AZ91 at $150{ }^{\circ} \mathrm{C}$ which has a slightly smaller E-value of about $43 \mathrm{GPa}$. Although the elastic modulus of $\mathrm{Mg}$ is normally taken as $45 \mathrm{GPa}$ [41] as the nominal value, the elastic modulus in $\mathrm{Mg}$ alloys can vary, depending on the metallurgical conditions, but it remains almost constant in the range of 39-45 GPa at RT [42] and up to $200{ }^{\circ} \mathrm{C}$ [43]. The modulus then decreases significantly with temperature [44], i.e., dropping to about $27 \mathrm{GPa}$ at $225^{\circ} \mathrm{C}$ in AZ31 [45]. Note that determining the elastic modulus in $\mathrm{Mg}$ alloys is difficult due to the small linear elastic region ( $<40 \mathrm{MPa})$. As reported by [22], the elastic modulus decreases when a higher stress level is used in modulus determination. For consistency, the E-value in this study is estimated from a stress level of $30 \mathrm{MPa}$. The secant elastic modulus (modulus value determined from the subsequent loops) then decreases with increasing applied plastic strain, reaching a minimum at about $0.6-1.2 \%$ plastic strain (as marked by symbol ' $\mathrm{O}$ '), slightly increasing afterwards. For all the alloys, the modulus consistently drops to a smaller value at RT, a consequence of loops being larger at RT (Figure 3). Both T5-aged AE44 and AZ91 are high-strength alloys and they exhibit a smaller decrease in modulus in general, in agreement with previous observations for high-strength alloys $[14,19]$.

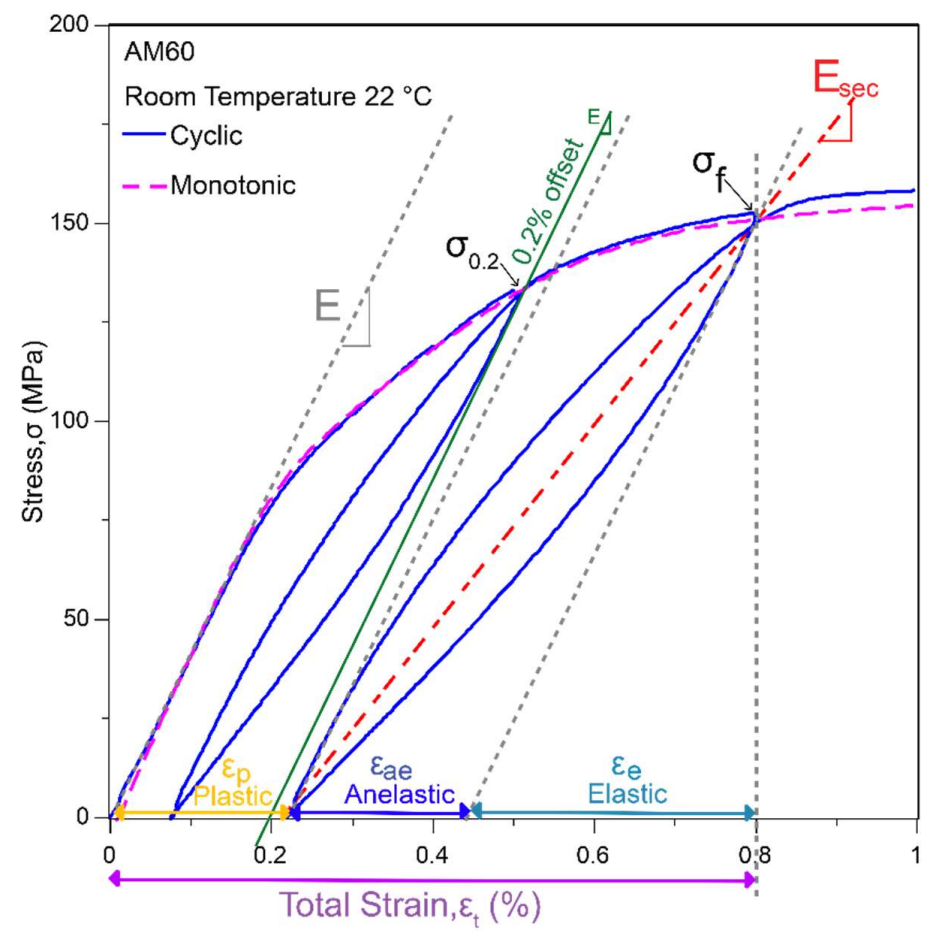

Figure 2. Cyclic tension loading-unloading test of die-cast AM60 at RT. The total strain $\left(\varepsilon_{\mathrm{t}}\right)$ is made up of linear elastic strain $\left(\varepsilon_{\mathrm{e}}\right)$, anelastic strain $\left(\varepsilon_{\mathrm{ae}}\right)$, and plastic strain $\left(\varepsilon_{\mathrm{p}}\right)$. E is the elastic modulus, while $\mathrm{E}_{\mathrm{sec}}$ is the secant elastic modulus. $\sigma_{\mathrm{f}}$ is the applied stress at the start of unloading, and $\sigma_{0.2}$ is the $0.2 \%$ offset yield stress. 

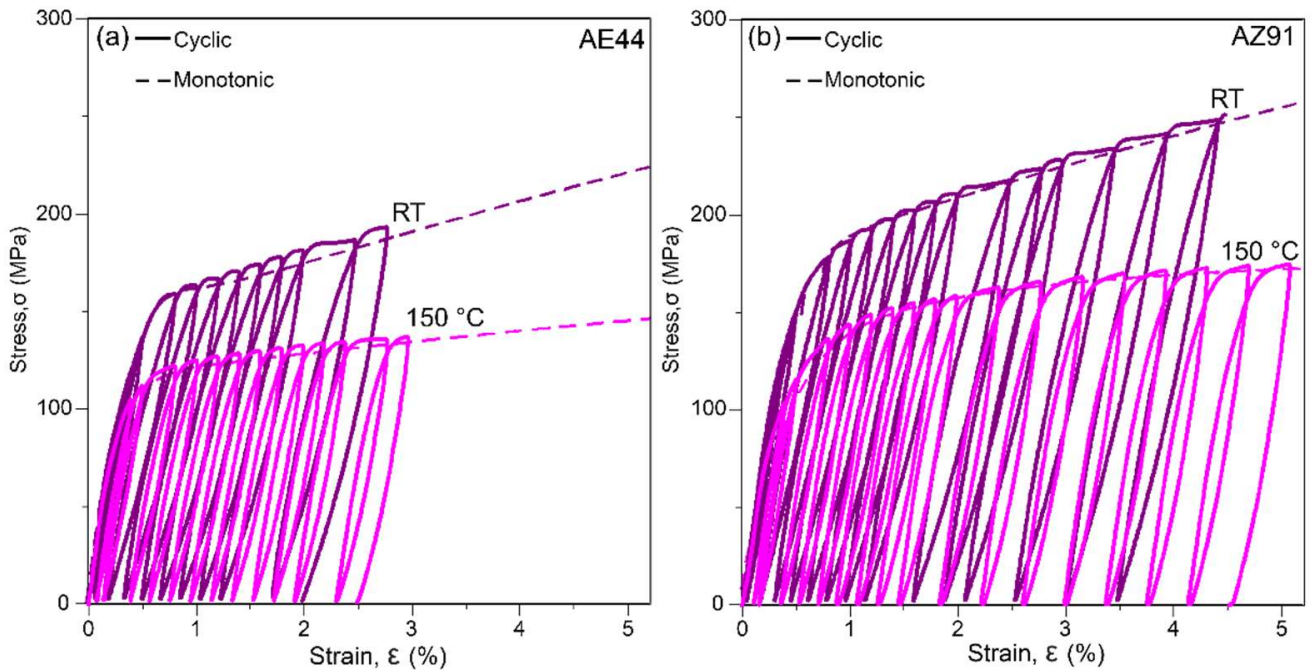

Figure 3. Examples of hysteresis loops in as-cast (a) AE44 and (b) AZ91 cycled in tension at RT and $150{ }^{\circ} \mathrm{C}$. Dashed line represents the corresponding monotonic flow curve.

Table 2. Monotonic tensile properties of studied die-cast Mg alloys at room and elevated temperatures.

\begin{tabular}{|c|c|c|c|c|c|}
\hline Alloy & $\begin{array}{c}\text { Temperature } \\
\left({ }^{\circ} \mathrm{C}\right)\end{array}$ & $\begin{array}{c}\text { Yield Strength by } \\
0.2 \% \text { Offset } \\
\text { Method (MPa) }\end{array}$ & $\begin{array}{l}\text { Yield Strength by Higher } \\
\text { Offset Strain Method a } \\
\text { (MPa) }\end{array}$ & $\begin{array}{l}\text { Tensile Strength } \\
\text { (MPa) }\end{array}$ & $\begin{array}{c}\text { Elongation to } \\
\text { Fracture (\%) }\end{array}$ \\
\hline \multirow{4}{*}{ AE44 } & RT & $133.0 \pm 1.4$ & $161.5 \pm 2.1$ & $292.5 \pm 6.3$ & $12.4 \pm 0.8$ \\
\hline & 50 & $126.0 \pm 5.3$ & $152.7 \pm 2.5$ & $294.0 \pm 5.6$ & $20.0 \pm 2.9$ \\
\hline & 100 & $116.0 \pm 2.8$ & $125.5 \pm 2.1$ & $246.0 \pm 2.8$ & $29.3 \pm 1.9$ \\
\hline & 150 & $106.0 \pm 1.4$ & $111.5 \pm 0.7$ & $194.5 \pm 0.7$ & $38.1 \pm 1.6$ \\
\hline \multirow{4}{*}{ T5-aged AE44 } & RT & $167.0 \pm 4.2$ & $194.5 \pm 0.7$ & $314.0 \pm 8.4$ & $11.4 \pm 1.9$ \\
\hline & 50 & $146.5 \pm 2.1$ & $181.0 \pm 0.3$ & $300.0 \pm 0.0$ & $15.5 \pm 0.2$ \\
\hline & 100 & $144.5 \pm 2.1$ & $156.5 \pm 2.1$ & $254.0 \pm 5.6$ & $30.8 \pm 2.3$ \\
\hline & 150 & $127.0 \pm 2.8$ & $134.0 \pm 2.8$ & $194.5 \pm 2.1$ & $30.7 \pm 1.8$ \\
\hline \multirow{4}{*}{ AM40 } & $\mathrm{RT}$ & $111.8 \pm 1.7$ & $132.5 \pm 3.0$ & $287.0 \pm 8.8$ & $17.8 \pm 1.8$ \\
\hline & 50 & $109.5 \pm 3.5$ & $131.0 \pm 1.4$ & $281.0 \pm 1.4$ & $17.3 \pm 0.4$ \\
\hline & 100 & $99.3 \pm 1.2$ & $109.0 \pm 1.7$ & $241.7 \pm 7.2$ & $20.9 \pm 2.6$ \\
\hline & 150 & $80.0 \pm 0.0$ & $89.0 \pm 1.4$ & $177.0 \pm 1.4$ & $27.6 \pm 1.3$ \\
\hline \multirow{4}{*}{ AM60 } & RT & $126.0 \pm 1.4$ & $148.0 \pm 0.2$ & $291.5 \pm 9.1$ & $13.7 \pm 1.4$ \\
\hline & 50 & $124.5 \pm 0.7$ & $149.0 \pm 0.1$ & $300.0 \pm 2.8$ & $16.1 \pm 0.4$ \\
\hline & 100 & $113.0 \pm 1.4$ & $124.5 \pm 3.5$ & $278.0 \pm 5.6$ & $20.7 \pm 2.3$ \\
\hline & 150 & $94.5 \pm 2.1$ & $105.5 \pm 0.7$ & $206.0 \pm 1.4$ & $25.2 \pm 1.2$ \\
\hline \multirow{4}{*}{ AZ91 } & RT & $163.0 \pm 2.8$ & $185.5 \pm 0.7$ & $274.6 \pm 13.3$ & $6.6 \pm 1.3$ \\
\hline & 50 & $140.5 \pm 0.7$ & $173.5 \pm 0.7$ & $258.5 \pm 0.7$ & $6.3 \pm 0.5$ \\
\hline & 100 & $124.5 \pm 0.7$ & $139.5 \pm 0.7$ & $270.0 \pm 11.3$ & $11.1 \pm 1.6$ \\
\hline & 150 & $111.0 \pm 6.0$ & $125.0 \pm 4.3$ & $220.3 \pm 13.1$ & $20.0 \pm 1.8$ \\
\hline
\end{tabular}

${ }^{a}$ Higher offset strains of $0.5 \%$ and $0.3 \%$ are applied for lower-temperature deformation RT- $50{ }^{\circ} \mathrm{C}$ and elevated-temperature deformation 100-150 ${ }^{\circ} \mathrm{C}$, respectively. 

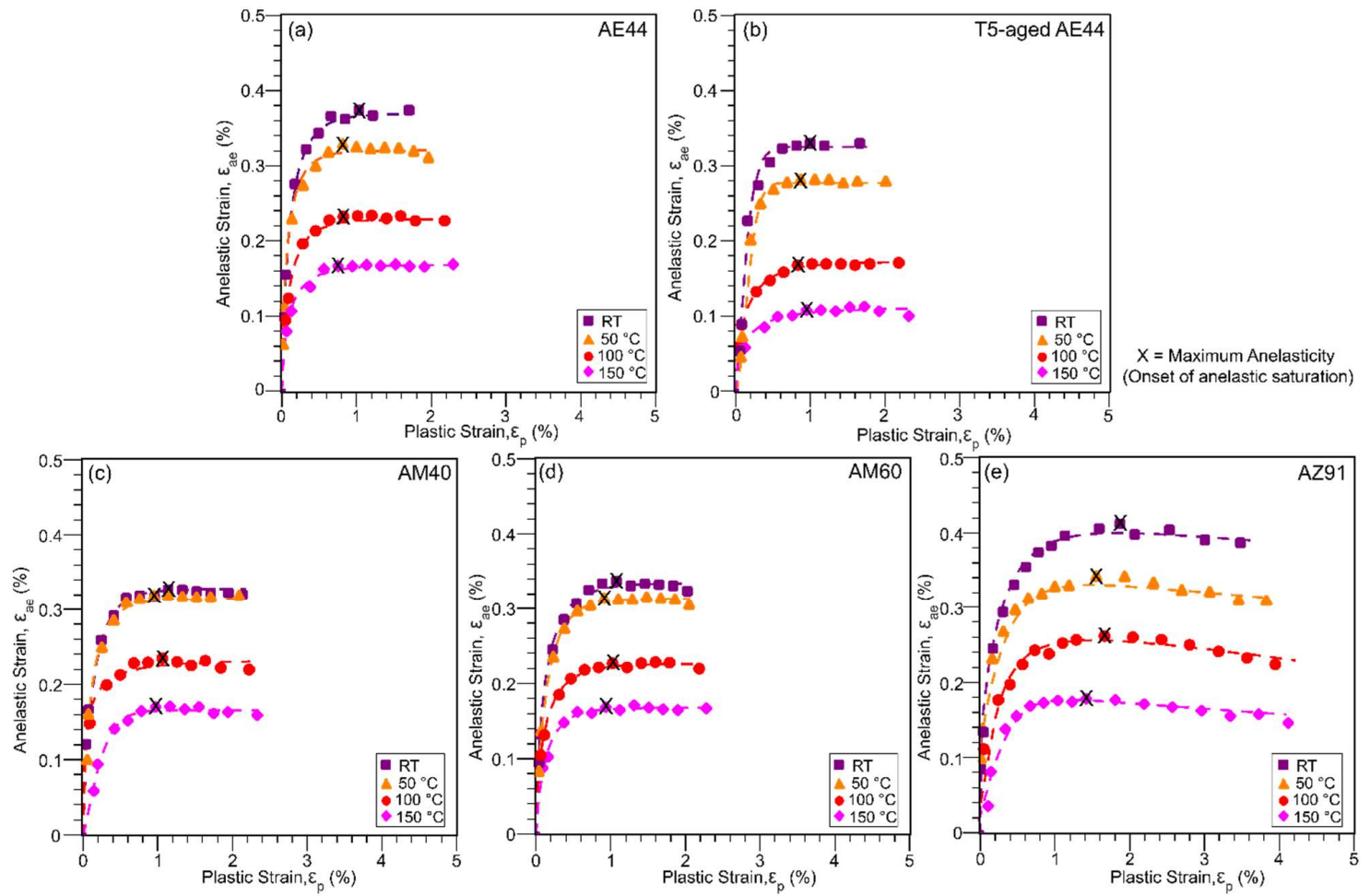

Figure 4. Anelastic strain, $\varepsilon_{\mathrm{ae}}$, as a function of the applied plastic strain, $\varepsilon_{\mathrm{p}}$, for (a) AE44, (b) T5-aged AE44, (c) AM40, (d) AM60, and (e) AZ91, at RT and elevated temperatures. Maximum anelasticity indicates the onset of anelastic saturation, as marked by the symbol ' $X$ '.
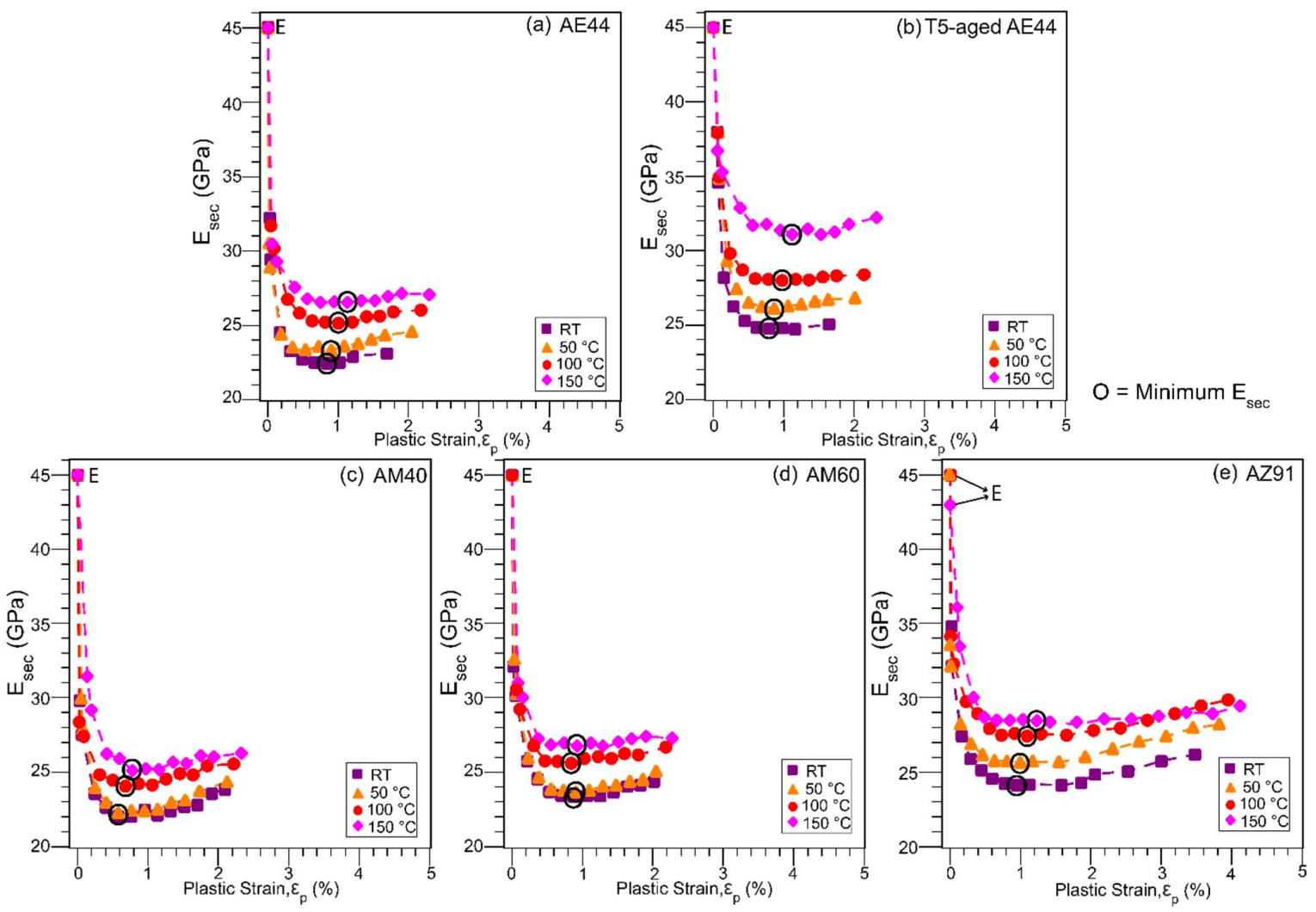

Figure 5. The secant elastic modulus, $\mathrm{E}_{\mathrm{sec}}$, as a function of the applied plastic strain, $\varepsilon_{\mathrm{p}}$, for the alloys and temperatures of Figure 4. E is the elastic modulus at zero plastic strain, estimated from a low stress region of $30 \mathrm{MPa}$. The symbol ' $\mathrm{O}$ ' denotes the minimum $\mathrm{E}_{\mathrm{sec}}$. 
Yielding is often defined by the stress at which $0.2 \%$ plastic strain occurs. Therefore, it is important to quantify the amount of anelastic strain and secant elastic modulus at $0.2 \%$ plastic strain, as shown in Figure 6a,b, respectively. Note that it is impossible to pre-identify the levels of stress and strain at which $0.2 \%$ plastic deformation occurs. In many cases, the hysteresis loops unloaded close to, but not exactly, $0.2 \%$ plastic strain during testing. In such cases, the anelastic strain and secant elastic modulus in Figure 6 are interpolated between the adjacent values (values measured from loops unloading to plastic strains before and after $0.2 \%$ ), leading to some deviations in the data. It is interesting to observe some amount of anelasticity at such a small plastic strain of $0.2 \%$; in particular, the anelastic component can be much larger than the plastic component at RT and $50{ }^{\circ} \mathrm{C}$ (above the dashed line in Figure 6a). The secant elastic modulus at $0.2 \%$ plastic strain is also much smaller than the nominal elastic modulus of $\mathrm{Mg}$ and $\mathrm{Mg}$ alloys, which is $45 \mathrm{GPa}$ [41].
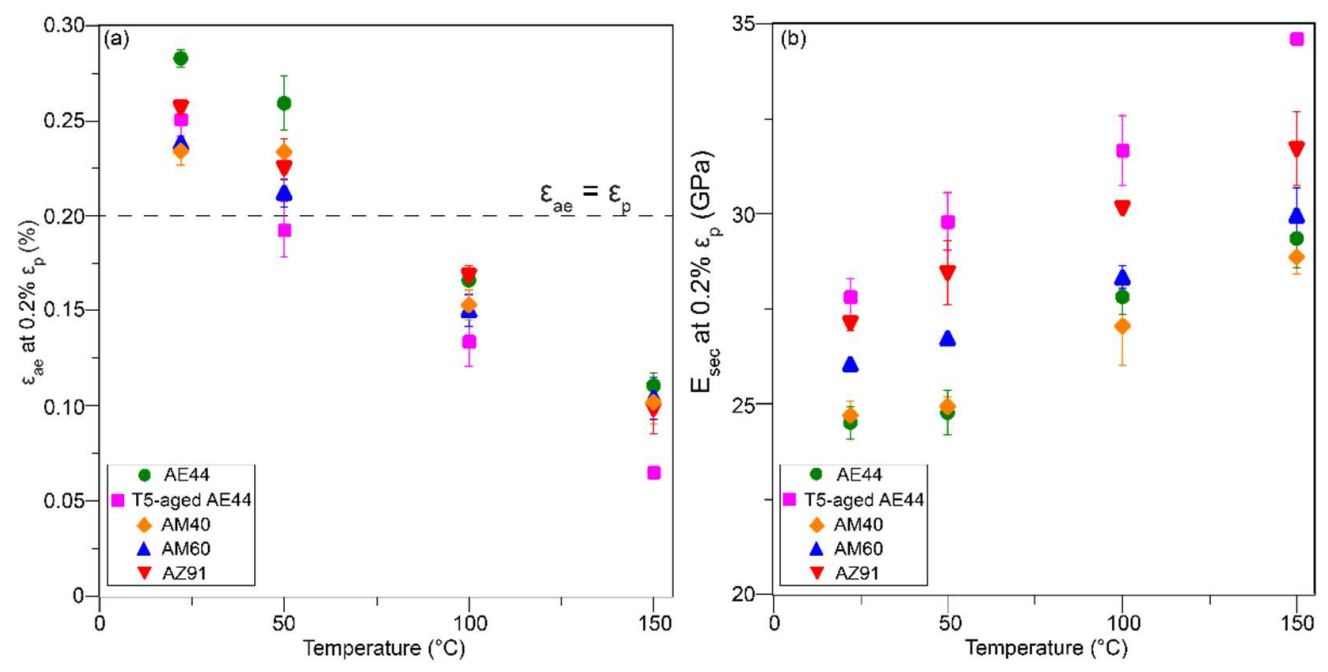

Figure 6. The magnitude of (a) anelastic strain, $\varepsilon_{\mathrm{ae}}$, and (b) secant elastic modulus, $\mathrm{E}_{\mathrm{sec}}$, at $0.2 \%$ plastic strain, $\varepsilon_{\mathrm{p}}$. The values shown are averaged from two to three repeated tests. Dashed line shown in (a) indicates $\varepsilon_{\mathrm{ae}}=\varepsilon_{\mathrm{p}}$.

The typical microstructures of the studied alloys are shown in Figure 7, which are characterised by primary $\alpha-\mathrm{Mg}$ dendrites (dark) surrounded by the eutectic consisting of intermetallic phase (light) in the interdendritic regions. For AE44 and T5-aged AE44, the dominant intermetallic phase is $\mathrm{Al}_{11} \mathrm{RE}_{3}$, which has a lamellar morphology and some minor $\mathrm{Al}_{2} \mathrm{RE}$ phase which has a polygonal shape. It is interesting to see no changes to the intermetallic phases after T5 ageing. For AM40, AM60, and AZ91, the intermetallic phase is $\mathrm{Mg}_{17} \mathrm{Al}_{12}$ [46,47], which appears as discrete particles surrounded by supersaturated eutectic $\alpha-\mathrm{Mg}$. Detailed characterisation of these types of intermetallic phases can be found in previous work [48-50].

The volume fraction of the brittle $\mathrm{Mg}_{17} \mathrm{Al}_{12}$ phase increases with increasing aluminium alloying, leading to an increase in hardness but reduction in ductility in AZ91. The distribution of $\mathrm{Al}$ solute in the $\alpha-\mathrm{Mg}$ matrix across the regions indicated in the SEM micrographs was measured by EDX and plotted in Figure 7. There is an increase in the Al solute concentration from the centre of the dendrite cells towards the boundaries. This is expected, as the eutectic containing intermetallic phases solidifies last during casting, and so it is richer in $\mathrm{Al}$ than the primary $\alpha-\mathrm{Mg}$ dendrites. The $\mathrm{Al}$ solute concentration near the dendrite boundaries and at the centre of the dendrite cells is recorded in Table 3.

EBSD maps of the as-cast and deformed microstructures after cyclic testing to 3\% strain at RT for AM60 and AZ91 are shown in Figure 8. It is clear that the as-cast microstructure is twin-free, and twins formed after cyclic deformation. The volume fraction of twinning in AZ91 is higher than AM60 and other alloys (not shown). Note that the twins shown in Figure 8 are the reverted twins because the samples were unloaded before EBSD analysis. 
These twins can partially revert by becoming larger upon reloading, initiating the anelastic property in Mg alloys. All the studied alloys have similar grain sizes $(\approx 8 \mu \mathrm{m})$ to eliminate grain size effect.
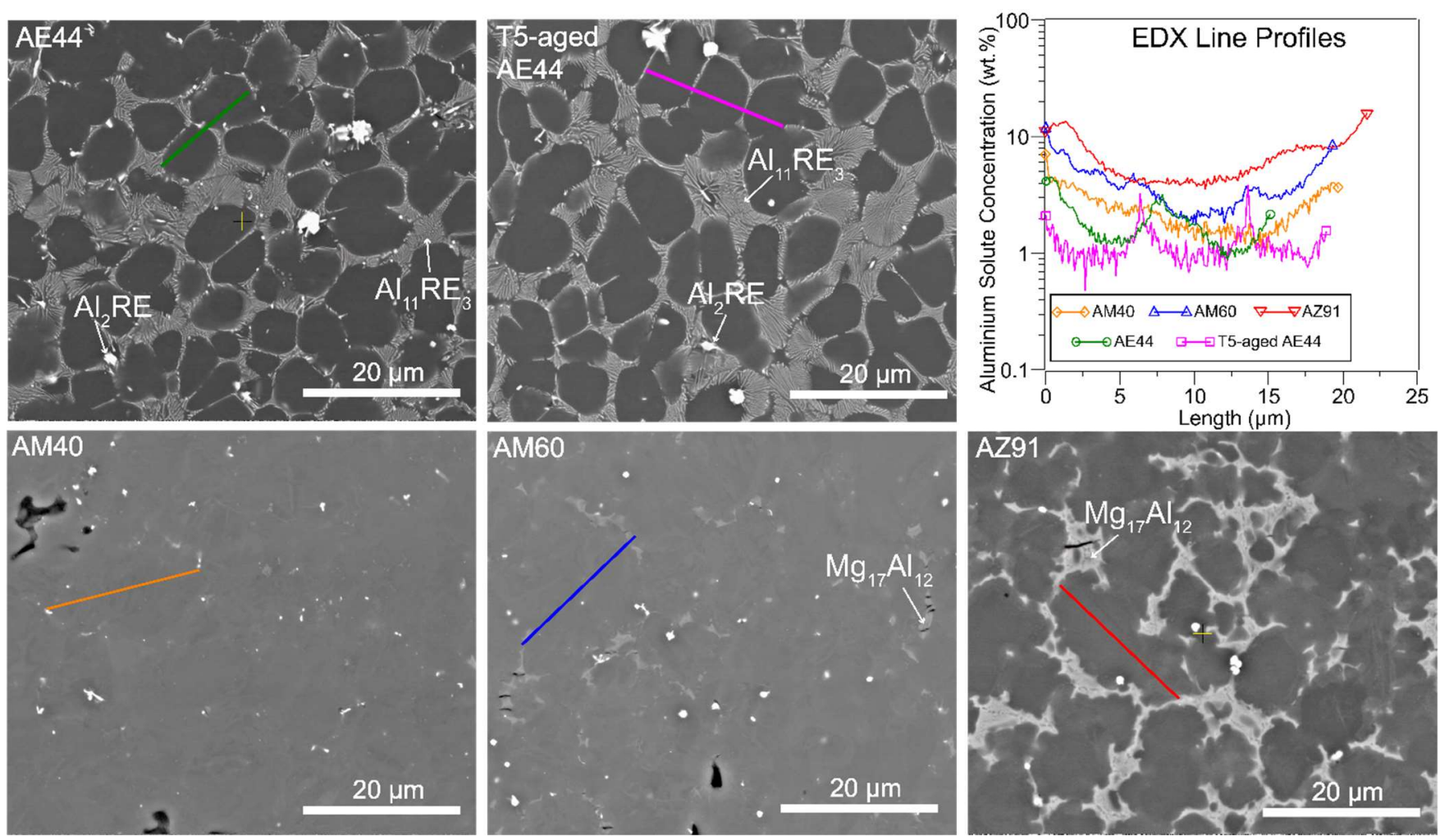

Figure 7. Backscattered SEM micrographs and EDX line profiles of the $\alpha$-magnesium matrix.

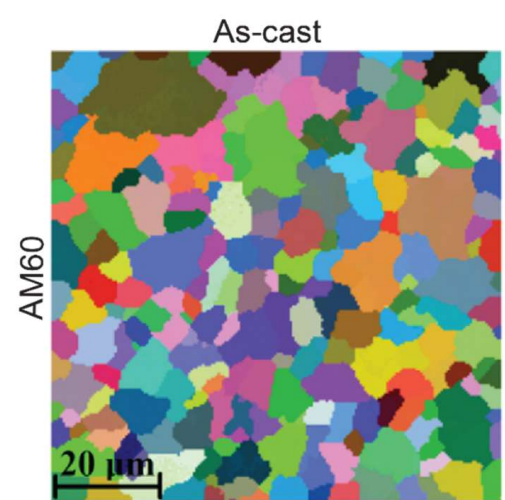

Cyclic deformed to $3 \%$ strain
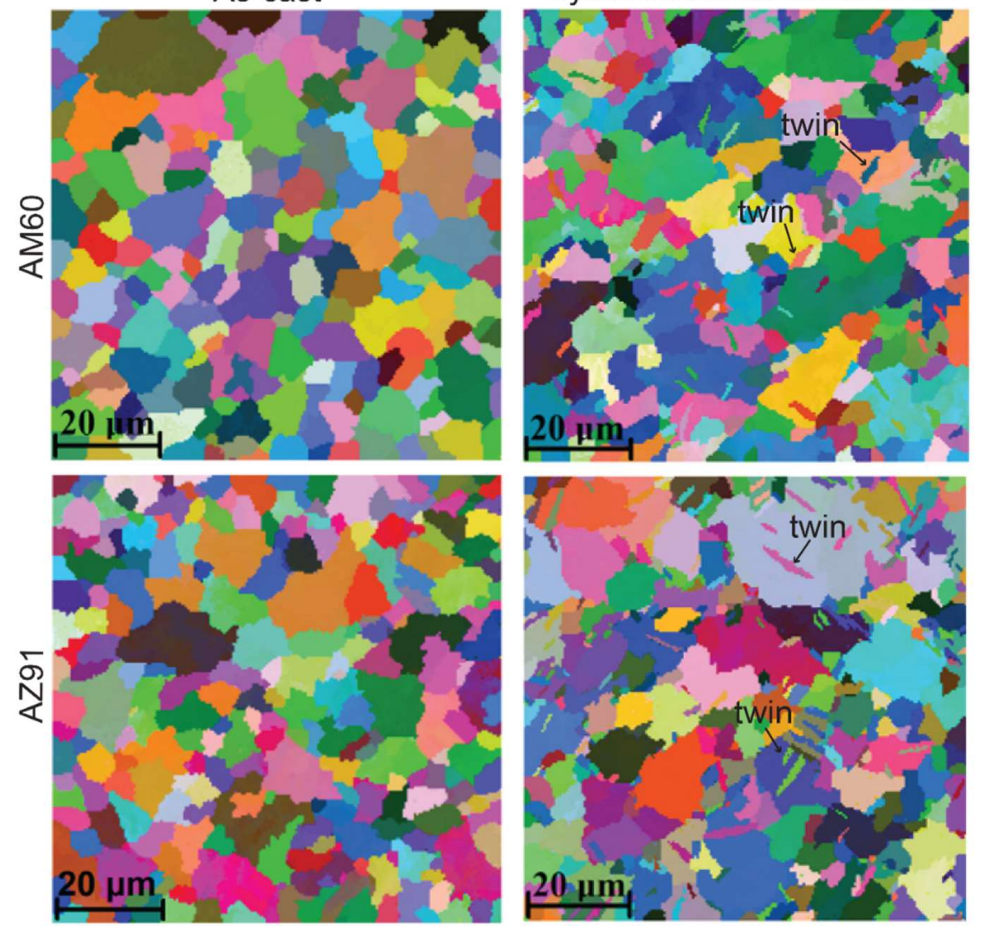

Figure 8. EBSD maps of AM60 and AZ91 showing twin-free as-cast microstructure and twin formation in deformed microstructure. 
Table 3. Al solute concentration level (wt.\%) in the $\alpha-\mathrm{Mg}$ matrix obtained by EDX.

\begin{tabular}{ccc}
\hline Alloy & Near Boundaries & Centre \\
\hline AE44 & $2-4$ & 1.7 \\
T5-aged AE44 & $2-3$ & 1.3 \\
AM40 & $4-7$ & 3.2 \\
AM60 & $8-11$ & 4.2 \\
AZ91 & $7-15$ & 7.4 \\
\hline
\end{tabular}

\section{Discussion}

The anelasticity behaviour observed in Figure 4, which increases with plastic strain and becomes saturated at a larger plastic strain, is consistent with previously published work $[19,51]$. When the deformation is small, below a plastic strain of $0.8-1 \%$ in AE and AM alloys or 1.4-1.8\% in AZ91, twins can multiply undisturbedly upon formation, and anelasticity increases with applied strain. When deformation is large, an increase in slip dislocation and twinning activity in the surrounding matrix can reduce the twin-boundary mobility, making untwinning more difficult [52], and consequently, saturating and eventually decreasing the anelastic strain (as observed in AZ91 beyond $2.4 \%$ plastic strain) as deformation continues. Note that the overall behaviour of $\mathrm{E}_{\mathrm{sec}}$ (Figure 5) corresponds to that of anelasticity (Figure 4), whereby an increase in anelasticity leads to a decrease in $E_{s e c}$ as the loops become larger, and vice versa. The minimum in $E_{s e c}$ and the maximum in anelastic strain occur at a slightly different plastic strains due to the work-hardening effect. The following discussion will now consider how temperature and alloy composition influence the anelastic behaviour and consequently affecting the yield strength measurement.

\subsection{The Effect of Temperature}

Present results show that anelasticity consistently decreases with increasing temperature (Figure 4); this applies even at very low plastic strain of $0.2 \%$ (Figure $6 a$ ), for all the studied alloys. This can be rationalised as follows. At RT deformation, $\mathrm{Mg}$ and $\mathrm{Mg}$ alloys have a limited number of basal slip systems [1]. Other non-basal slip systems, such as prismatic slip, first order and second order pyramidal slip are also less favoured as their critical resolved shear stresses (CRSSs) at RT are several orders of magnitude greater than that of basal slip and twinning [53,54]. Therefore, to meet the von Mises' criterion, which requires five independent systems for homogeneous deformation [6], \{1012\} twinning, which has the smallest CRSS, is profusely activated, magnifying the anelasticity at RT.

As temperature increases, the CRSSs of non-basal slip systems are known to decrease significantly even to a smaller level than the CRSS of $\{10 \overline{1} 2\}$ twinning $[53,55]$. This is because, unlike the non-basal slip which is highly sensitive to temperature [56,57], the CRSS of $\{10 \overline{1} 2\}$ twinning is not temperature sensitive [58,59]. Die-cast alloys have random texture, and no specific deformation mechanism is favoured [60-62]; therefore, each deformation mechanism, such as slip and twinning, will be activated when the local stress acting upon them reaches their CRSS. As the non-basal slip systems become easier to activate at higher temperature, while $\{10 \overline{1} 2\}$ twinning is not affected by temperature, the relative propensity for twinning and untwinning decreases, thereby reducing the maximum anelasticity with increasing temperature. At low plastic strain of $0.2 \%$ (Figure 6a), the larger amount of anelasticity compared to plasticity at RT-50 ${ }^{\circ} \mathrm{C}$ suggests that twinning is the dominant deformation mode at least up to $50^{\circ} \mathrm{C}$; non-basal slip may become increasingly prominent beyond $50{ }^{\circ} \mathrm{C}$ as indicated by the smaller anelasticity than plasticity at $100-150{ }^{\circ} \mathrm{C}$. In fact, it has been widely reported that the improved ductility of $\mathrm{Mg}$ alloys at elevated temperature (Table 2) is the result of the activation of these non-basal slip systems [63,64].

\subsection{The Effect of Alloy Composition}

In Mg-Al alloys without RE addition AM40, AM60 and AZ91, AZ91 exhibits the largest maximum anelasticity, while AM40 and AM60 appear to have similar maximum 
anelasticity at a given temperature (Figure 4). Since the studied alloys have similar grain sizes, the main difference is the $\mathrm{Al}$ concentration. AZ91 has the highest $\mathrm{Al}$ solute concentration in the $\alpha-\mathrm{Mg}$ matrix compared to AM60 and AM40 as shown in Figure 7. Firstly, high $\mathrm{Al}$ concentration produces solid solution hardening of slip planes (increase the CRSS of slip), but $\mathrm{Al}$ has little hardening effect on twinning [15,30], the net result being more twinning is activated to assist plastic deformation. This correlates well with the EBSD analysis in Figure 8, which shows higher volume fraction of twinning in AZ91 than AM60. Secondly, increasing $\mathrm{Al}$ concentration increases the twin growth stress (suppresses twin growth), resulting in formation of numerous smaller and unstable twins [17]. These two effects can increase the tendency of untwinning, magnifying the maximum anelasticity in AZ91. Since slip becomes more difficult to activate in AZ91, twins can easily untwin without the interference of slip (abundance of slip dislocation can decrease twin-boundary mobility and untwinning [52]) until slip is profusely activated at higher stresses and strains. This explains the delayed saturation of anelasticity at $1.4-1.8 \%$ plastic strain in AZ91 as compared to $\sim 0.8-1 \%$ in other alloys. Note that ease of activation of non-basal slip at 150 ${ }^{\circ} \mathrm{C}$ in AZ91 may counteract the hardening effect of $\mathrm{Al}$, resulting in saturation of anelasticity at a smaller plastic strain of $\sim 1.4 \%$ compared to $1.8 \%$ at RT.

The similar anelasticity between AM40 and AM60 can be explained as follows. A small addition of $\mathrm{Al}$ solute up to $0.5 \mathrm{wt}$.\% was confirmed to soften the prismatic plane (decrease the CRSS of prismatic slip); higher solute level was not investigated in [65]. However, later work by Nagarajan et al. [15] showed softening of prismatic plane up to 2 wt.\% of Al; hence, the present work suggests that prismatic plane may undergo a transition from softening to hardening with increasing $\mathrm{Al}$ concentration from AM40 to AZ91. It is likely that AM40 and AM60 are in the softening-hardening transition region in which $\mathrm{Al}$ has little effect on prismatic slip. Since Al forms near-random solid solutions [29] and also does not have any hardening effect on twinning [15,30], and hence, the similar maximum anelasticity of AM40 and AM60 at all temperatures.

In Mg-Al-RE alloy AE44, T5 ageing may also influence the anelastic deformation, as T5-aged AE44 consistently shows smaller maximum anelasticity, regardless of the temperatures. Although AE44 and T5-aged AE44 have similar intermetallic phases, there was a formation of Al-Mn nanoscale precipitates after T5 ageing, as reported recently [66]. These precipitates may serve as obstacles to twinning and untwinning as twins propagate along the twin boundaries, decreasing the twin-boundary mobility. Hence, untwinning becomes more difficult and decreases the maximum anelasticity in T5-aged AE44.

Note that it is more complex to compare between $\mathrm{Mg}-\mathrm{Al}-\mathrm{RE}$ and $\mathrm{Mg}-\mathrm{Al}$ alloys due to microstructural difference, as shown in Figure 7, and it may not provide meaningful results. Besides, studies showed that the degree of interconnection of the percolating intermetallic network of $\mathrm{Mg}_{17} \mathrm{Al}_{12}$ has a measurable effect on the work hardening $[67,68]$ and the anelastic deformation [69]. It is, however, not known if the Al-RE intermetallic network has the same effect.

\subsection{The Effect of Anelasticity and $E_{\text {sec }}$ on Yield Strength Measurement}

The yield strength of materials is generally measured by offsetting the linear elastic modulus, $E$ to some amount of permanent plastic strain. The amount of permanent plastic strain can range from $0.1 \%$ for ferrous to $0.5 \%$ for non-ferrous materials [37], and $0.2 \%$ is used for $\mathrm{Mg}$ and $\mathrm{Mg}$ alloys. However, unloading at $0.2 \%$ offset yield stress, $\sigma_{0.2}$, leaves only a very small fraction of permanent plastic strain $(<0.1 \%)$ due to the reversible anelastic component of $\mathrm{Mg}$ and $\mathrm{Mg}$ alloys, as illustrated in Figure 2. Clearly, this conventional $0.2 \%$ offset method underestimates the yield strength of $\mathrm{Mg}$ alloys without considering the anelastic effect. To accurately measure the $0.2 \%$ permanent strain yield stress, elastic modulus of Mg (normally taken as $45 \mathrm{GPa}$ ) should be offset to a higher strain value. This higher offset strain method should consider the anelasticity at $0.2 \%$ plastic strain [22]. Figure $9 \mathrm{a}$ is a conversion chart which shows the appropriate offset strains (plastic strain plus anelastic strain) for as-cast AE44 (solid symbol) and AZ91 (hollow symbol). The 
offset strain to achieve a $0.2 \%$ permanent strain upon unloading can range from $0.3 \%$ for alloys deforming at higher temperatures $\left(100-150{ }^{\circ} \mathrm{C}\right)$ to $0.5 \%$ for alloys deforming at low temperatures (RT-50 ${ }^{\circ} \mathrm{C}$ ). This range is also applicable for other studied alloys (not shown), as the anelasticity at $0.2 \%$ plasticity (Figure $6 \mathrm{a}$ ) is quite similar between the alloys, but different between the temperatures.
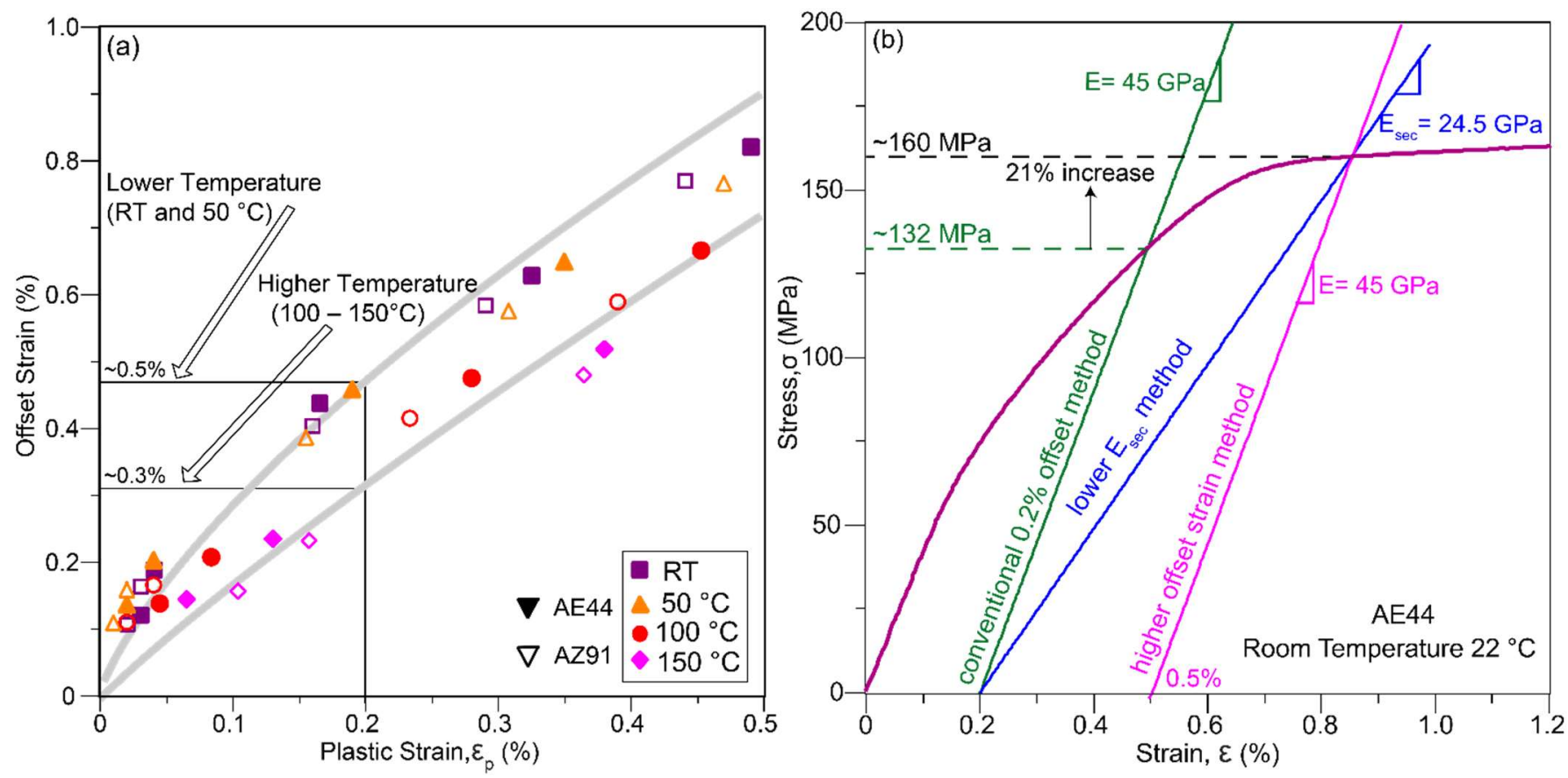

Figure 9. (a) Appropriate offset strains (plastic strain + anelastic strain) for as-cast AE44 and AZ91 at room and elevated temperatures, and (b) comparison of proposed yield strength measurement methods (higher offset strain and lower $E_{\text {sec }}$ methods) with the conventional $0.2 \%$ offset method.

Alternatively, a lower $\mathrm{E}_{\text {sec }}$ (Figure $6 \mathrm{~b}$ ) should be applied at $0.2 \%$ strain to achieve a more diagnostic property value than the widely used elastic modulus of $45 \mathrm{GPa}$. Both the proposed higher offset strain and lower $\mathrm{E}_{\mathrm{sec}}$ methods are compared with the conventional $0.2 \%$ offset method in Figure $9 \mathrm{~b}$, and their measured yield stress values are reported in Table 2. Higher offset strain method crosses the flat part of the curve, and it provides a more consistent yield stress value as noted by the smaller sample to sample variations (Table 2) than the $0.2 \%$ offset method. From Table 2 and Figure $9 b$, it is clear that the yield strength of the studied alloys is largely underestimated by up to $20 \%$ using the $0.2 \%$ offset method. The $0.2 \%$ offset method may be applicable to most steel and aluminium which have only linear elastic and plastic properties, but in $\mathrm{Mg}$ and $\mathrm{Mg}$ alloys, higher offset strain or lower $E_{\text {sec }}$ methods should be employed to achieve a more accurate yield stress value which leaves a permanent plastic strain close to $0.2 \%$ upon unloading.

\section{Conclusions}

The anelastic deformation, attributed to partial reversal of $\{10 \overline{2} 2\}$ twinning, of several commercial die-cast $\mathrm{Mg}$ alloys has been studied from room temperature to $150^{\circ} \mathrm{C}$ under cyclic tension loading-unloading testing. The following conclusions can be drawn.

1. The magnitude of anelastic strain decreases with increasing temperature. This is ascribed to the ease of activation of non-basal slip at temperatures beyond $50{ }^{\circ} \mathrm{C}$, reducing the propensity for twinning to occur as a deformation mechanism, and thereby lowering the amount of reversible twinning. The improved tensile ductility of the alloys at elevated temperature is the result of the activation of non-basal slip systems. 
2. In Mg-Al alloys, AZ91 consistently shows the largest maximum anelasticity, while AM40 and AM60 have similar anelasticity at all temperatures. The effects can be understood in terms of solid solution hardening and softening of slip system by the $\mathrm{Al}$ solute, leading to a change in twinning and untwinning (anelasticity) activity.

3. In Mg-Al-RE alloy, T5-aged AE44 consistently exhibits smaller maximum anelasticity compared to as-cast AE44. T5 ageing forms Al-Mn nanoscale precipitates, and these precipitates may decrease twin-boundary mobility, making partial reversal of twinning more difficult.

4. Anelasticity observed in $\mathrm{Mg}$ alloys leads to inaccuracy in yield strength measurement using the conventional $0.2 \%$ offset method. Higher offset strain or lower $\mathrm{E}_{\mathrm{sec}}$ methods, which account for the anelastic effect, are proposed to improve the accuracy of the yield strength measurement for die-cast magnesium alloys.

Author Contributions: This is a sole-author paper. H.Q.A.: Conceptualization, Methodology, Validation, Investigation, Writing, Review and Editing. All authors have read and agreed to the published version of the manuscript.

Funding: This research received no external funding.

Institutional Review Board Statement: Not applicable.

Informed Consent Statement: Not applicable.

Data Availability Statement: The raw/processed data required to reproduce these findings cannot be shared at this time, as the data also form part of an ongoing study.

Acknowledgments: Magnesium samples used in this work were produced by the CSIRO Manufacturing Flagship with acknowledgement of Trevor Abbott. The author also acknowledges the use of the RMIT Microscopy and Microanalysis Facility. This research did not receive any specific grant from funding agencies in the public, commercial, or not-for-profit sectors.

Conflicts of Interest: The authors declare no conflict of interest.

\section{References}

1. Partridge, P.G. The crystallography and deformation modes of hexagonal close-packed metals. Met. Rev. 1967, 12, 169-194. [CrossRef]

2. Akhtar, A.; Teghtsoonian, E. Solid-solution hardening in magnesium alloys. J. Investig. Med. 1968, 9, $692-697$.

3. Stanford, N.; Barnett, M. Solute strengthening of prismatic slip, basal slip and twinning in $\mathrm{Mg}$ and $\mathrm{Mg}-\mathrm{Zn}$ binary alloys. Int. J. Plast. 2013, 47, 165-181. [CrossRef]

4. Agnew, S.; Brown, D.; Tome, C. Validating a polycrystal model for the elastoplastic response of magnesium alloy AZ31 using in situ neutron diffraction. Acta Mater. 2006, 54, 4841-4852. [CrossRef]

5. Mises, R.V. Mechanik der plastischen Formänderung von Kristallen. ZAMM 1928, 8, 161-185. [CrossRef]

6. Taylor, G.I. Plastic strain in metals. J. Inst. Met. 1938, 62, 307-324.

7. Barnett, M.R. Twinning and the ductility of magnesium alloys: Part I: “Tension" twins. Mater. Sci. Eng. A 2007, 464, 1-7. [CrossRef]

8. Obara, T.; Yoshinga, H.; Morozumi, S. $\{11 \overline{2} 2\}<1123>$ Slip system in magnesium. Acta Met. 1973, 21, 845-853. [CrossRef]

9. Duerig, T.; Zadno, R. An engineer's perspective of pseudoelasticity. In Engineering Aspects of Shape Memory Alloys; Duerig, T., Melton, K.N., Stöckel, D., Wayman, C., Eds.; Butterworth-Heinemann: Oxford, UK, 1990; pp. 369-393.

10. Muránsky, O.; Carr, D.; Sittner, P.; Oliver, E. In situ neutron diffraction investigation of deformation twinning and pseudoelasticlike behaviour of extruded AZ31 magnesium alloy. Int. J. Plast. 2009, 25, 1107-1127. [CrossRef]

11. Gharghouri, M.A.; Weatherly, G.C.; Embury, J.D.; Root, J. Study of the mechanical properties of Mg-7.7at.\% Al byin-situneutron diffraction. Philos. Mag. A 1999, 79, 1671-1695. [CrossRef]

12. Lee, S.; Gharghouri, M. Pseudoelastic behavior of magnesium alloy during twinning-dominated cyclic deformation. Mater. Sci. Eng. A 2013, 572, 98-102. [CrossRef]

13. Cui, Y.; Li, Y.; Wang, Z.; Ding, X.; Koizumi, Y.; Bian, H.; Lin, L.; Chiba, A. Impact of solute elements on detwinning in magnesium and its alloys. Int. J. Plast. 2017, 91, 134-159. [CrossRef]

14. Mann, G.; Sumitomo, T.; Cáceres, C.; Griffiths, J. Reversible plastic strain during cyclic loading-unloading of Mg and Mg-Zn alloys. Mater. Sci. Eng. A 2007, 456, 138-146. [CrossRef]

15. Nagarajan, D.; Ren, X.; Caceres, C. Anelastic behavior of Mg-Al and Mg-Zn solid solutions. Mater. Sci. Eng. A 2017, 696, 387-392. [CrossRef] 
16. Nagarajan, D. Anelasticity in cast Mg-Gd alloys. Mater. Sci. Eng. A 2017, 695, 14-19. [CrossRef]

17. Drozdenko, D.; Čapek, J.; Clausen, B.; Vinogradov, A.; Máthis, K. Influence of the solute concentration on the anelasticity in Mg-Al alloys: A multiple-approach study. J. Alloys Compd. 2019, 786, 779-790. [CrossRef]

18. Koike, J.; Fujiyama, N.; Ando, D.; Sutou, Y. Roles of deformation twinning and dislocation slip in the fatigue failure mechanism of AZ31 Mg alloys. Scr. Mater. 2010, 63, 747-750. [CrossRef]

19. Caceres, C.; Sumitomo, T.; Veidt, M. Pseudoelastic behaviour of cast magnesium AZ91 alloy under cyclic loading-unloading. Acta Mater. 2003, 51, 6211-6218. [CrossRef]

20. Lu, Z.; Blackmore, P. Cyclic Stress-Strain Behaviour of AM60B and AE44 Cast Magnesium Alloys and Its Impact on LCF Characterisation and Fatigue Analysis. SAE Int. J. Mater. Manuf. 2014, 7, 446-453. [CrossRef]

21. Ang, H.Q.; Zhu, S.M.; Abbott, T.B.; Easton, M.A. Anelastic deformation during cyclic loading-unloading of die-cast magnesium alloys. In Proceedings of the 11th International Conference on Magnesium Alloys and Their Applications, Old Winsor, UK, 24-27 July 2018; Fan, Z., Mendis, C., Eds.; Brunel University Press: London, UK, 2018; pp. 165-168.

22. Ang, H.Q.; Abbott, T.B.; Zhu, S.; Gu, C.; Easton, M.A. Proof stress measurement of die-cast magnesium alloys. Mater. Des. 2016, 112, 402-409. [CrossRef]

23. Joost, W.J.; Krajewski, P.E. Towards magnesium alloys for high-volume automotive applications. Scr. Mater. 2017, 128, 107-112. [CrossRef]

24. Luo, A.; Renaud, J.; Nakatsugawa, I.; Plourde, J. Magnesium castings for automotive applications. JOM 1995, 47, 28-31. [CrossRef]

25. Nagarajan, D.; Caceres, C.; Griffiths, J. Anelastic Phenomena in Mg-Al Alloys. Acta Phys. Pol. A 2012, 122, 501-504. [CrossRef]

26. Li, B.; Kadiri, H.E.I.; Zhang, X.Y.; Mathaudhu, S.N.; Ma, Q. Structural origin of reversible twinning, non-schmid effect, incoherent twin boundaries and texture of hexagonal close-packed metals. In Magnesium Technology 2012, Proceedings of the TMS; Mathaudhu, S.N., Sillekens, W.H., Neelameggham, N.R., Hort, N., Eds.; The Minerals, Metals \& Materials Society: Orlando, FL, USA, 2012; pp. 105-110.

27. Cahn, J.W. Thermodynamic and structural changes in deformation twinning of alloys. Acta Met. 1977, 25, 1021-1026. [CrossRef]

28. Cáceres, C.H.; Blake, A. The strength of concentrated Mg-Zn solid solutions. Phys. Stat. Sol. A 2002, 194, 147-158. [CrossRef]

29. Cáceres, C.; Rovera, D. Solid solution strengthening in concentrated Mg-Al alloys. J. Light Met. 2001, 1, 151-156. [CrossRef]

30. Ang, H.Q.; Abbott, T.B.; Zhu, S.; Easton, M. Anelasticity of die-cast magnesium-aluminium based alloys under different strain rates. Mater. Sci. Eng. A 2017, 707, 101-109. [CrossRef]

31. Ang, H.Q. Mechanical Properties and Deformation Behaviour of High-Pressure Die-Cast Magnesium-Aluminium based Alloys. Ph.D. Thesis, RMIT University, Melbourne, Australia, 2017.

32. Aragones, J.; Goundan, K.; Kolp, S.; Osborne, R.; Ouimet, L.; Pinch, W. Development of the 2006 Corvette Z06 Structural Cast Magnesium Crossmember; SAE Technical Paper Series, 2005-01-0340; SAE International: Warrendale, PA, USA, 2005. [CrossRef]

33. Luo, A.A. Recent Magnesium Alloy Development for Automotive Powertrain Applications. Mater. Sci. Forum 2003, 419-422, 57-66. [CrossRef]

34. Ang, H.Q.; Zhu, S.; Abbott, T.B.; Qiu, D.; Easton, M.A. Strain-rate sensitivity of die-cast magnesium-aluminium based alloys. Mater. Sci. Eng. A 2017, 699, 239-246. [CrossRef]

35. Nagasekhar, A.V.; Easton, M.A.; Cáceres, C.H. Solute content and the grain microstructure of high pressure die cast magnesiumaluminium alloys. Adv. Eng. Mater. 2009, 11, 912-919. [CrossRef]

36. Zhu, S.; Abbott, T.; Gibson, M.; Nie, J.; Easton, M. Age hardening in die-cast Mg-Al-RE alloys due to minor Mn additions. Mater. Sci. Eng. A 2016, 656, 34-38. [CrossRef]

37. ISO 6892-1. Metallic Materials Tensile Testing-Part 1: Method of Test at Room Temperature; International Standards Organisation (ISO): Geneva, Switzerland, 2009; p. 65.

38. Dørum, C.; Hopperstad, O.; Lademo, O.-G.; Langseth, M. Numerical modelling of the structural behaviour of thin-walled cast magnesium components. Int. J. Solids Struct. 2005, 42, 2129-2144. [CrossRef]

39. Easton, M.; Song, W.Q.; Abbott, T. A comparison of the deformation of magnesium alloys with aluminium and steel in tension, bending and buckling. Mater. Des. 2006, 27, 935-946. [CrossRef]

40. ASTM. E8M-09: Standard test methods for tension testing of metallic materials. In Annual Book of ASTM Standards; American Society for Testing and Materials: West Conshohocken, PA, USA, 2009; p. 127.

41. Avedesian, M.; Baker, H. Magnesium and Magnesium Alloys-ASM Specialty Handbook; ASM International The Materials Information Society: Novelty, OH, USA, 1999; Volume 52.

42. Sumitomo, T.; Cáceres, C.; Veidt, M. The elastic modulus of cast Mg-Al-Zn alloys. J. Light Met. 2002, 2, 49-56. [CrossRef]

43. Garlea, E.; Radovic, M.; Liaw, P. High-temperature dependency of elastic mechanical behavior of two wrought magnesium alloys AZ31B and ZK60A studied by resonant ultrasound spectroscopy. Mater. Sci. Eng. A 2019, 758, 86-95. [CrossRef]

44. Göken, J.; Riehemann, W. Damping behaviour of AZ91 magnesium alloy with cracks. Mater. Sci. Eng. A 2003, 370, 417-421. [CrossRef]

45. Hama, T.; Kariyazaki, Y.; Ochi, K.; Fujimoto, H.; Takuda, H. Springback Characteristics of Magnesium Alloy Sheet AZ31B in Draw-Bending. Mater. Trans. 2010, 51, 685-693. [CrossRef]

46. Rettberg, L.H.; Jordon, J.B.; Horstemeyer, M.F.; Jones, J.W. Low-Cycle Fatigue Behavior of Die-Cast Mg Alloys AZ91 and AM60. Met. Mater. Trans. A 2012, 43, 2260-2274. [CrossRef] 
47. Chadha, G.; Allison, J.E.; Jones, J.W. The Role of Microstructure on Ductility of Die-Cast AM50 and AM60 Magnesium Alloys. Met. Mater. Trans. A 2007, 38, 286-297. [CrossRef]

48. Rzychoń, T.; Kiełbus, A.; Cwajna, J.; Mizera, J. Microstructural stability and creep properties of die casting Mg-4Al-4RE magnesium alloy. Mater. Charact. 2009, 60, 1107-1113. [CrossRef]

49. Zhu, S.; Nie, J.; Gibson, M.; Easton, M.; Bakke, P. Microstructure and Creep Behavior of High-Pressure Die-Cast Magnesium Alloy AE44. Met. Mater. Trans. A 2012, 43, 4137-4144. [CrossRef]

50. Srinivasan, A.; Pillai, U.T.S.; Pai, B.C. Microstructure and mechanical properties of Si and Sb added AZ91 magnesium alloy. Met. Mater. Trans. A 2005, 36, 2235-2243. [CrossRef]

51. Fallahi, H.; Tabarroki, M.; Davies, C. Evolution of anelastic behaviour and twinning in cyclic loading of extruded magnesium alloy ZM21. Mater. Sci. Eng. A 2020, 770, 138520. [CrossRef]

52. Reed-Hill, R.; Dahlberg, E.; Slippy, W., Jr. Some anelastic effects in zirconium at room temperature resulting from prestrain at 77 deg K. Trans. Met. Soc. AIME 1965, 233, 21748.

53. Barnett, M. A taylor model based description of the proof stress of magnesium AZ31 during hot working. Met. Mater. Trans. A 2003, 34, 1799-1806. [CrossRef]

54. Agnew, S.R. Plastic anisotropy of magnesium alloy AZ31B Sheet. In Essential Readings in Magnesium Technology; Mathaudhu, S.N., Luo, A.A., Neelameggham, N.R., Nyberg, E.A., Sillekens, W.H., Eds.; Springer: Cham, Switzerland, 2016; pp. 351-356.

55. Ulacia, I.; Dudamell, N.; Galvez, F.; Yi, S.; Pérez-Prado, M.; Hurtado, I. Mechanical behavior and microstructural evolution of a Mg AZ31 sheet at dynamic strain rates. Acta Mater. 2010, 58, 2988-2998. [CrossRef]

56. Yoshinaga, H.; Horiuchi, R. On the Nonbasal Slip in Magnesium Crystals. Trans. Jpn. Inst. Met. 1964, 5, 14-21. [CrossRef]

57. Chapuis, A.; Driver, J.H. Temperature dependency of slip and twinning in plane strain compressed magnesium single crystals. Acta Mater. 2011, 59, 1986-1994. [CrossRef]

58. Barnett, M.; Keshavarz, Z.; Beer, A.; Atwell, D. Influence of grain size on the compressive deformation of wrought Mg-3Al-1Zn. Acta Mater. 2004, 52, 5093-5103. [CrossRef]

59. Meyers, M.; Vöhringer, O.; Lubarda, V. The onset of twinning in metals: A constitutive description. Acta Mater. 2001, 49, 4025-4039. [CrossRef]

60. Lu, Y.; Taheri, F.; Gharghouri, M. Monotonic and Cyclic Plasticity Response of Magnesium Alloy. Part I. Experimental Response of a High-Pressure Die Cast AM60B. Strain 2008, 47, e15-e24. [CrossRef]

61. Xu, S.; Tyson, W.; Eagleson, R.; Zavadil, R.; Liu, Z.; Mao, P.-L.; Wang, C.-Y.; Hill, S.; Luo, A. Dependence of flow strength and deformation mechanisms in common wrought and die cast magnesium alloys on orientation, strain rate and temperature. $J$. Magnes. Alloys 2013, 1, 275-282. [CrossRef]

62. Agnew, S.; Yoo, M.; Tomé, C. Application of texture simulation to understanding mechanical behavior of Mg and solid solution alloys containing Li or Y. Acta Mater. 2001, 49, 4277-4289. [CrossRef]

63. Wonsiewicz, B.; Backofen, W. Independent slip systems and ductility of hexagonal polycrystals. Trans. Metall. Soc. AIME 1967, 239, 1422-1433.

64. Agnew, S.R.; Duygulu, O. Plastic anisotropy and the role of non-basal slip in magnesium alloy AZ31B. Int. J. Plast. 2005, 21, 1161-1193. [CrossRef]

65. Akhtar, A.; Teghtsoonian, E. Solid solution strengthening of magnesium single crystals-II the effect of solute on the ease of prismatic slip. Acta Met. 1969, 17, 1351-1356. [CrossRef]

66. Zhu, S.; Abbott, T.B.; Nie, J.-F.; Ang, H.Q.; Qiu, D.; Nogita, K.; Easton, M.A. Re-evaluation of the mechanical properties and creep resistance of commercial magnesium die-casting alloy AE44. J. Magnes. Alloys 2021, 9, 1537-1545. [CrossRef]

67. Zhang, B.; Nagasekhar, A.V.; Sivarupan, T.; Caceres, C.H. Deformation Behavior of the Percolating Intermetallic Microstructure of High Pressure Die Cast AZ91 Alloy. Adv. Eng. Mater. 2013, 15, 1059-1067. [CrossRef]

68. Zhang, B.; Yang, K.V.; Nagasekhar, A.V.; Cáceres, C.H.; Easton, M. Deformation Behavior of the Percolating Eutectic Intermetallic in HPDC and Squeeze-Cast Mg Alloys. JOM 2014, 66, 2086-2094. [CrossRef]

69. Ang, H.Q.; Abbott, T.B.; Zhu, S.; Easton, M.A. An Analysis of the Tensile Deformation Behavior of Commercial Die-Cast Magnesium-Aluminum-Based Alloys. Met. Mater. Trans. A 2019, 50, 3827-3841. [CrossRef] 